\title{
Hubungan Stres Akademik dengan Flow Akademik pada Mahasiswa
}

\author{
Annisa Gatari \\ Fakultas Psikologi, Universitas Muhammadiyah Malang \\ e-mail: annisagatari1208@gmail.com
}

\begin{abstract}
Students have various kinds of demands and obstacles on academic assignments that can make students experiencing academic stress. Academic stress make students feel uncomfortable, less focus, lack of concentration, and uncomfortable with academic activities which is called academic flow. The purpose of this was to determine the relationship between academic stress and academic flow in students. This research is a quantitative study with subjects being psychology students at the University of Muhammadiyah Malang 7st grade, and 174 subjects. The sampling technique used is nonprobability sampling, namely purposive sampling and analysis techniques using product moment correlation test with SPSS 24 . The results of data analysis obtained the value of $r=-, 359, p=0.000$ (sig $<0.01$ ) meaning this study shows the relationship between the two variables and in accordance with the hypothesis that the higher the academic stress the lower the academic flow in students. Vice versa, the lower the academic stress, the higher the academic flow in students. The effective contribution of academic stress to academic flow is $12.9 \%$ and the remainder is $87.1 \%$, influenced by other factors.
\end{abstract}

\section{KEYWORDS Academic stress, academic flow}

CITATION Gatari, A. (2020). Hubungan stres akademik dengan flow akademik pada mahasiswa. Cognicia, 8, (1), 422-431

Mahasiswa merupakan seorang yang sedang dalam proses menimba ilmu ataupun belajar dan terdaftar sedang menjalani pendidikan pada salah satu perguruan tinggi (Hartaji, 2012). Mahasiswa dapat didefinisikan sebagai individu yang sedang menuntut ilmu di perguruan tinggi, baik itu negeri maupun swasta atau lembaga lain yang setingkat dengan perguruan tinggi. Mahasiswa dinilai memiliki tingkat intelektualitas yang tinggi. Memiliki kecerdasan dalam berpikir dan perencanaan dalam bertindak. Memiliki pemikiran yang kritis dan dapat bertindak dengan cepat dan tepat itu semua merupakan sifat yang cenderung melekat pada setiap mahasiswa (Siswoyo, 2007).

Mahasiswa memiliki berbagai macam tuntutan dan hambatan dalam perkuliahan. Hambatan dan tuntutan yang dihadapi antara lain tugas kuliah yang harus diselesaikan dalam waktu bersamaan, praktikum, pencapaian beban studi, dan skripsi. Berbagai macam tugas yang dihadapi dapat membuat mahasiswa merasa tidak nyaman sehingga tidak menikmati kegiatan akademik dan sulit berkonsentrasi. Menurut Yuwanto, dkk (2011) konsentrasi dan menikmati kegiatan adalah modal utama mengerjakan tugas kuliah. 
Hambatan yang dialami mahasiswa tidak membuat mudah menyerah, tetapi mahasiswa tetap mengerjakan proses belajar dan mengerjakan tugas perkuliahan. Tugas yang dikerjakan sesuai dengan kemampuan dan minat akan membuat pekerjaan tersebut terasa ringan dan menyenangkan. Hal tersebut yang membuat mahasiswa tidak mudah menyerah dan tetap mengerjakan tugas dengan optimal. Kondisi mudah merasakan kenikmatan, bahagia dalam aktivitas yang dilakukan, berkonsentrasi dengan baik, merasa nyaman, dan memiliki motivasi internal disebut dengan flow. Flow menurut Csikszentmihalyi (2014) ialah pengalaman terlibat penuh dalam suatu kegiatan dengan perasaan menyenangkan dan fokus. Flow berdampak pada kinerja yang lebih baik dibandingkan jika tidak mengalami flow (Csikszentmihalyi, 1990).

Menurut Csikzentmihalyi (dalam Bakker, 2005) mahasiswa membutuhkan flow dalam proses akademik. Flow akademik penting bagi mahasiswa agar mampu tetap fokus dan berkonsentrasi dalam menyelesaikan tugas maupun perkuliahan meskipun mengalami kesulitan dalam proses menjalani masa perkuliahan. Daniel Goleman (2015) berpendapat bahwa flow adalah keadaan ketika perhatian seseorang hanya terfokus pada pekerjaan yang dilakukan. Mampu mencapai keadaan flow merupakan puncak kecerdasan emosional yang dapat menumbuhkan perasaan senang dan bahagia. Ciri-ciri flow pada seseorang menurut Salanova, Bakker, dan Llorens (2006) yaitu: Absorption (keadaan seseorang dapat berkonsentrasi dengan penuh pada aktivitas yang dilakukan), Work Enjoyment (perasaan nyaman dalam melakukan aktivitas yang dilakukan), Intrinsic Work Motivation (keinginan dari dalam diri sendiri untuk melakukan aktivitasnya dan bukan karena mendapatkan reward atau dari faktor lain).

Flow memiliki dampak positif terhadap performa belajar pada setiap indiviu. Hasil penelitian yang dilakukan oleh Shernoff (2003) menunjukkan bahwa individu yang mengalami flow memiliki keinginan untuk terlibat di dalam proses belajar, individu juga mengalami peningkatan performa dalam akademik, lebih merasa bersemangat saat mendapatkan tugas yang cukup menantang, dan cenderung lebih baik dalam hal atensi, mood serta motivasi belajar dibandingkan individu lain yang tidak mengalami flow. Individu yang tidak mengalami flow, memiliki kecenderungan mengalami kejenuhan dalam proses pembelajaran sehingga menyebabkan atensi dan mood individu tidak dalam keadaan yang baik. Hal tersebut dapat mempengaruhi fokus dalam proses pembelajaran.

Menurut Csikszentmihalyi (dalam Bakker, 2005) mahasiswa membutuhkan flow dalam proses akademik. Bagi mahasiswa, flow merupakan hal yang sangat penting dimiliki agar tetap dapat berkonsentrasi sekalipun menghadapi kesulitan atau hambatan. Yuwanto (2011) mengungkapkan bahwa flow memiliki manfaat bagi individu yaitu memberikan pengalaman optimal pada aktivitas yang dikerjakan, mudah dalam memahami informasi yang diterima, memiliki kualitas kerja yang optimal, dan mengalami pengembangan diri. Perasaan nyaman dan fokus yang dirasakan akan memunculkan perilaku inovatif, mudah menyerap pengetahuan, dan perasaan nyaman pada aktivitas yang dilakukan (Yuwanto, dkk 2013). Flow dibidang akademik dibutuhkan oleh mahasiswa, karena dapat memberikan hasil yang postif berupa mengurangi stres akademik (Rupayana, 2008). 
Pada penelitian Melisa Santoso (2014) menunjukkan bahwa adanya hubungan positif antara self efficacy dan flow akademik. Menurut Bakker (dalam Rupayana, 2008) meningkatnya perasaan menikmati, konsentrasi penuh, dan munculnya motivasi internal yang memenuhi semua aspek flow akademik, sehingga menurut korelasi antara aspek flow akademik dan self efficacy akademik, meningkatnya self efficacy akademik akan meningkatkan terjadinya flow akademik. Sedangkan pada penelitian Robin Ignatus (2013) tentang go with the flow: dukungan sosial dan flow akademik pada mahasiswa. Penelitian tersebut memberikan hasil bahwa terdapat hubungan positif antara dukungan sosial dengan flow akademik, jadi ketika seseorang mahasiswa mendapatkan dukungan sosial maka mahasiswa tersebut dapat merasa nyaman dan senang ketika mengikuti kegiatan akademik ataupun mengerjakan tugas-tugas akademiknya.

Adapun flow bagi individu yaitu memberikan pengalaman optimal pada aktivitas yang dikerjakan, mudah dalam memahami informasi yang diterima, memiliki kualitas kerja yang optimal dan mengalami pengembangan diri (Yuwanto, 2011). Hal ini akan dapat membuat individu merasa nyaman dan fokus, sehingga dapat memunculkan perilaku inovatif, mudah menyerap pengetahuan dan perasaan nyaman pada aktivitas yang dilakukan (Yuwanto dan Patricia, 2013). Menurut Csikszentmihalyi (2014) ada dua faktor yang memperngaruhi kondisi flow yaitu internal dan eksternal. Faktor internal yaitu faktor yang berasal dalam diri individu seperti tingkat kemampuan yang dimiliki, setiap individu memiliki persepsi dalam melihat suatu tugas yang dimiliki, memiliki motivasi dalam diri dan kondisi emosi, kemudian faktor eksternal yaitu faktor dari lingkungan, terkait seberapa besar tantangan tugas yang diberikan kepada individu. Faktor-faktor lain yang ditemukan memiliki korelasi dengan flow akademik adalah student engagement, motivasi berprestasi, dukungan sosial, stres akademik, self esteem, dan self efficacy. Salah satu hal yang dapat mempengaruhi individu mengalami kondisi flow adalah stres akademik.

Stres akademik adalah suatu kondisi atau keadaan dimana terjadi ketidaksesuaian antara tuntutan lingkungan dengan sumber daya aktual yang dimiliki sehingga mereka semakin terbebani oleh berbagai tekanan dan tuntutan (Rahmawati, 2003). Stres akademik juga diidentifikasikan dengan banyaknya tugas yang diberikan, kompetisi dengan teman lain, mengalami kegagalan, mempunyai hubungan relasi yang kurang antara sesama, dengan lingkungan, sistem semester dan kekurangan sumber belajar (Angolia dan Ongiro dalam Rahmawati, 2012).

Jika individu tidak dapat mengatasi tantangan tersebut maka individu tersebut dapat mengalami stres. Stres merupakan salah satu respon individu terhadap keadaan atau kejadian yang memicu stres, yang mengancam dan menganggu kemampuan seseorang (Santrock, 2003). Stres secara normal dialami oleh setiap individu dan sudah menjadi bagian dalam kehidupan. Stres yang paling umum dialami oleh mahasiswa adalah stres akademik seperti mengingat tingginya kompleksitas masalah yang dihadapi sehingga mengakibatkan pola pikir seseorang menjadi kacau. Mahasiswa tidak hanya dituntut mempunyai keterampilan teknis tapi juga diharapkan memiliki daya dan kerangka pikir serta sikap mental dan kepribadian tertentu sehingga mempunyai wawasan luas dalam menghadapi masalah dalam lingkungan sosialnya. 
Pada penelitian Zuama (2014) bahwa pada mahasiswa semester 1 sampai 8 (semester akhir) cenderung mengalami stres. Stres yang dialami mahasiswa diantaranya adalah memiliki IPK yang rendah, merasa terlalu berat dalam hal kurikulum, kurikulum mengalami perubahan, adanya peraturan akademik yang ketat diperguruan tinggi, mahasiswa harus mengerjakan tugas sesuai dengan deadline, hambatan dalam menyelesaikan tugas akhir dan adanya tuntutan dari orangtua. Selain itu, mahasiwa juga memiliki keinginan untuk meraih gelar Cumlaude, tuntutan untuk segera menyelesaikan kuliah dan banyak mengikuti kegiatan organisasi sehingga waktu istirahat berkurang, serta jarang masuk kedalam kelas dan kurang aktif dalam mengikuti proses pembelajaran di kelas. Mahasiswa yang tidak mampu menyelesaikan tuntutan akademik yang dihadapi dapat memunculkan stress yang disebut dengan stres akademik.

Dinamika akademik merupakan hal yang harus dihadapi khususnya bagi mahasiswa, berbagai stimulus yang ada seperti halnya dengan deadline pengumpulan tugas, tugas yang banyak, praktikum yang beruntun, menghadapi dosen yang sulit, memperoleh hasil ujian yang buruk, tidak lulus mata kuliah tertentu, tugas akhir skripsi yang dirasa berat dan sebagainya. Seorang mahasiswa sering dihadapkan pada berbagai macam tanggung jawab dan kewajiban yang berat berkaitan dengan tugas bidang akademik, tidak jarang mahasiswa mengalami stres dalam menjalaninnya. Hal ini dapat menjadi salah satu stres bagi mahasiswa (Sho'imah, 2010). Dampak negatif stres akademik yang dialami mahasiswa diantaranya penurunan indeks prestasi, gangguan memori, konsentrasi, kemampuan menyelesaikan masalah dan kemampuan akademik (Goff, 2011).

Berdasarkan fenomena yang telah dipaparkan di atas, rumusan permasalahan pada penelitian ini ialah apakah terdapat hubungan stres akademik dengan flow akademik. Sehingga tujuan dari penelitian ini yaitu mengetahui hubungan stres akademik dengan flow akademik. Adapun manfaat dari penelitian ini sebagai acuan dan referensi untuk penelitian selanjutnya mengenai stres akademik dan flow akademik. Selain itu, penelitian ini juga bermanfaat untuk memberikan pengetahuan dan informasi kepada masyarakat mengenai pentingnya flow akademik pada diri individu dalam menjalani suatu aktivitas akademik dan penelitian ini diharapkan dapat memberikan kontribusi, sebagai bahan tambahan refrensi untuk penelitian selanjutnya.

\section{METODE}

Jenis penelitian ini merupakan penelitian kuantitatif. Penelitian ini ditunjukkan untuk mengetahui seberapa jauh variasi suatu variabel yang berkaitan dengan variabel lainnya yang didasarkan pada koefesien korelasi (Azwar, 2012).

Populasi yang diambil dalam penelitian ini adalah mahasiswa Fakultas Psikologi di Universitas Muhammadiyah Malang Semester 7. Subyek dalam penelitian ini berjumlah 174 mahasiswa. Teknik pengambilan sampel yang digunakan adalah nonprobability sampling, yaitu purposive sampling, adalah teknik pengambilan sampel dari sumber data dengan pertimbangan tertentu. Alasan menggunakan teknik Purposive Sampling karena tidak semua sampel memiliki kriteria yang sesuai dengan fenomena yang diteliti. Oleh karena itu, peneliti memilih teknik Purposive Sampling 
untuk menetapkan pertimbangan-pertimbangan atau kriteria-kriteria tertentu yang harus dipenuhi oleh sampel-sampel dalam penelitian ini (Sugiyono, 2016).

Variabel-variabel yang digunakan ialah variabel bebas dan variabel terikat. Adapaun yang menjadi variabel bebas adalah stres akademik dan yang menjadi variabel terikat adalah flow akademik.

Stres akademik merupakan respon psikologis yang muncul karena terlalu banyaknya tuntutan dan tugas yang harus dikerjakan mahasiswa. Instrument untuk mengukur stres akademik mengadaptasi skala yang digunakan oleh Ansori (2015), dengan berlandaskan teori Potter dan Perry. Aitem dalam skala ini memiliki 14 butir pernyataan yang bersifat favourable, dan 10 butir pernyataan yang bersifat unfavourable. Sehingga total item dalam skala ini berjumlah 24 item. Pada skala stres akademik memiliki indeks reliabilitas sebesar 0,842 dan dari 24 item yang disajikan valid dengan indeks reliabilitas berkisar antara 0,242 sampai 0,670.

Flow akademik adalah pengalaman untuk terlibat secara efektif dan menyenangkan dalam proses akademik sehingga bisa memunculkan motivasi. Flow merupakan suatu kondisi, dimana siswa mencapai titik fokus dalam proses pembelajaran. Untuk mengukur flow akademik mengadaptasi skala the flow inventory for student (LIS) yang dikembangkan oleh Yuwanto (2011), berlandaskan teori Csikszentmihaly \& Shernof. Aitem dalam skala ini memiliki 13 butir pernyataan yang bersifat favourable, dan 9 butir pernyataan bersifat unfavourable. Sehingga total item dalam skala ini berjumlah 22 item. Pada skala flow akademik memiliki indeks reliabilitas sebesar 0,856 dan 22 item yang disajikan memiliki indeks reliabilitas berkisar antara 0,288 sampai 0,661.

Kedua skala yang digunakan adalah skala Likert yang terdiri dari empat kategori jawaban yaitu sangat setuju (SS), sesuai (S), tidak sesuai (TS), dan sangat tidak sesuai (STS). Untuk bobot penilaian pernyataan favorable adalah $\mathrm{SS}=4, \mathrm{~S}=3, \mathrm{TS}=2, \mathrm{STS}=1$. Sedangkan bobot penilaian dari pernyataan unfavorable adalah $S S=1, S=2, T S=3$, dan $\mathrm{STS}=4$.

Penelitian ini menggunakan tiga prosedur utama yaitu yang pertama tahap persiapan terdiri dari melakukan pendalaman materi dan studi kepustakaan dari berbagai sumber seperti jurnal, buku dan penelitian terdahulu, melakukan adaptasi skala stres akademik dan flow akademik, serta melakukan try out alat ukur atau instrumen penelitian untuk menguji validitas dan realibilitas. Tahap kedua yaitu melakukan uji coba atau try out kepada 60 responden yang berstatus sebagai mahasiswa aktif dan analisis data untuk mengetahui validitas dan reliabilitas. Setelah instrument diuji coba, tahap ketiga adalah pengambilan data dengan jumlah subyek pada penelitian ini sebanyak 174 responden dari Fakultas Psikologi semester 7 di Universitas Muhammadiyah Malang dengan menggunakan bantuan aplikasi IBM spss for windows version 21.0 untuk melakukan analisa data dan selanjutnya melakukan pembahasan hasil penelitian, membuat hasil diskusi dan kesimpulan.

\section{HASIL}

Jumlah subyek dalam penelitian ini berjumlah 174 subyek dengan jenis kelamin laki-laki dan perempuan, yang sedang menempuh jenjang pendidikan di Universitas Muhammadiyah Malang jurusan Psikologi semester 7. Jumlah subyek 
yang berjenis kelamin laki-laki sebanyak 59 mahasiswa, dan sedangkan subyek yang berjenis kelamin perempuan sebanyak 115 mahasiswi.

Tabel 1. Kategori Skala Stres Akademik \& Flow Akademik

\begin{tabular}{cccccc}
\hline \multicolumn{3}{c}{ Stres Akademik } & \multicolumn{3}{c}{ Flow Akademik } \\
\hline Kategori & Frekuensi & Presentase & Kategori & Frekuensi & Presentase \\
\hline Rendah & 33 & $19 \%$ & Rendah & 5 & $3 \%$ \\
Sedang & 119 & $68 \%$ & Sedang & 91 & $52 \%$ \\
Tinggi & 22 & $13 \%$ & Tinggi & 78 & $45 \%$ \\
\hline Total & 174 & $100 \%$ & Total & 174 & $100 \%$ \\
\hline
\end{tabular}

Berdasarkan tabel 1 dapat kita ketahui kategori stres akademik dan flow akademik. Subyek menunjukkan stres akademik kategori rendah berjumlah 33 orang (19\%), kategori sedang berjumlah 119 orang (68\%) dan yang terakhir dalam kategori tinggi berjumlah 22 orang (13\%). Selanjutnya pada skala flow akademik dalam kategori rendah berjumlah 5 orang (3\%), kategori sedang berjumlah 91 orang (52\%) dan yang terakhir kategori tinggi berjumlah 78 orang $(45 \%)$.

Tabel 2. Deskripsi Data Variabel Stres Akademik dan Flow Akademik

\begin{tabular}{cccc}
\hline Variabel & N & SD & Mean \\
\hline Stres Akademik & \multirow{2}{*}{174} & 10,61 & 60 \\
Flow Akademik & & 8,01 & 55 \\
\hline
\end{tabular}

Pada tabel 2 dapat kita ketahui bahwa subyek dalam penelitian berjumlah 174 dan dalam variabel stres akademik memiliki nilai standar deviasi sebesar 10,61 dan mean sebesar 60 sedangkan pada variabel pada flow akademik memiliki nilai standar deviasi sebesar 8,01 dan mean sebesar 55 .

Tabel 3. Hasil Analisis Korelasional Stres Akademik \& Flow Akademik

\begin{tabular}{cc}
\hline & Indeks Analisis \\
\hline Koefisien Korelasi $(\mathbf{r})$ &,- 359 \\
Koefisien Diterminasi $\left(\boldsymbol{r}^{2}\right)$ & 12,9 \\
Taraf Kemungkinan Kesalahan & $0,01(1 \%)$ \\
P (Nilai Signifikasi) & 0,00 \\
$\mathbf{N}$ & 174 \\
\hline
\end{tabular}

Pada tabel 3 di atas berisi hasil analisa data menggunakan uji Pearson Product Moment di SPSS 21 dapat disimpulkan bahwa ada hubungan antara Stres Akademik \& Flow Akademik. Hal tersebut diketahui dari hasil koefisian korelasi (r) sebesar -,359, koefisien determinasi $\left(r^{2}\right)$ sebesar 12,9 dengan tingkat signifikasi 1\% (r: -,359, p: 0,00). Artinya terdapat hubungan antara kedua variabel sesuai dengan hipotesis yang diajukan yaitu semakin tinggi stres akademik maka semakin rendah flow akademik pada mahasiswa. Begitu pula sebaliknya, semakin rendah stres akademik maka semakin tinggi flow akademik pada mahasiswa. 


\section{DISKUSI}

Berdasarkan hasil analisis data diperoleh nilai koefisien korelasi $\mathrm{r}=-, 359$ dengan $\mathrm{p}=0,00(\mathrm{p}<0,01)$. Hal ini menunjukkan bahwa terdapat hubungan negatif yang sangat signifikan antara stres akademik dengan flow akademik. Artinya semakin tinggi stres akademik mahasiswa maka akan semakin rendah flow akademik mahasiswa dan sebaliknya semakin rendah stres akademik mahasiswa maka akan semakin tinggi flow akademik mahasiswa. Sumbangan efektif menunjukkan seberapa besar peran atau kontribusi variabel bebas terhadap variabel terikat. Sumbangan efektif variabel stres akademik terhadap flow akademik ditunjukkan oleh nilai $\mathrm{r}$ sebesar -,359 kemudian dikuadratkan $\left(\left(\mathrm{r}^{2}\right)\right.$ sebesar 12,9).

Dari hasil kategori stres akademik pada mahasiswa diperoleh pesentase 19\% yang memiliki stres akademik yang rendah, $68 \%$ yang memiliki stres akademik yang sedang dan $13 \%$ memiliki stres akademik yang tinggi. Dari hasil flow akademik diperoleh hasil presentase yaitu 3\% yang memiliki flow akademik yang rendah, 52\% yang memiliki flow akademik yang sedang dan 45\% memiliki flow akademik yang tinggi.

Berdasarkan hasil analisis diketahui bahwa stres akademik dan flow akademik tergolong dalam kategori sedang. Hal ini dapat diinterpretasikan bahwa subyek dalam penelitian ini memiliki tingkat stres akademik dan flow akademik yang baik. Jika mahasiswa mengalami stres akademik dalam perkuliahan maka akan kesulitan mengalami kondisi flow. Dalam penelitian Chlarasinta (2015) mengatakan bahwa mahasiswa yang mengalami stres akademik harus dapat memiliki pengelolaan dalam menghadapi tuntutan-tuntutan akademik dengan menenangkan diri dan menjalankan aktivitas perkuliahan seperti biasa, berusaha untuk membuat nyaman dengan menikmati setiap proses yang dijalani, berusaha mencari referensi diluar seperti perpustakaan maupun internet, mengerjakan sedikit demi sedikit tugas yang sudah diberikan dosen, membuat manajemen waktu, menyusun jadwal pembuatan tugas dan belajar, serta berpikir positif. Hal tersebut sesuai dengan penelitian yang dilakukan oleh Yuwanto, dkk (2011) menunjukkan persentase terbesar mahasiswa mengalami flow dalam kategori sedang yaitu 59,2\%. Ini menunjukkan tidak semua mahasiswa dapat mengalami flow karena mengalami stres akademik. Sejalan dengan bukti empiris yang menunjukkan ada korelasi negatif antara stres akademik dan flow $(\mathrm{r}=-, 251)$. Artinya mahasiswa yang mengalami stres akademik akan kesulitan mencapai flow dalam melakukan aktivitas akademik. Konsentrasi dan menikmati aktivitas akademik merupakan modal yang paling utama bagi mahasiswa untuk mengerjakan tugas-tugas perkuliahan. Flow juga dapat memberikan manfaat bagi mahasiswa antara lain dapat membuat mahasiswa lebih fokus, kreatif, lebih mudah menyerap materi perkuliahan sehingga berdampak pada hasil belajar yang optimal (Yuwanto, dkk 2011).

Stres akademik pada subyek penelitian tergolong sedang dapat dikatakan bahwa mahasiswa ketika menjawab pertanyaan dari dosen atau teman-teman saat presentasi dikelas merasa tenang, pola makan mahasiswa tidak berubah, porsi makan nya juga tidak mengalami perubahan, nilai hasil ujian tidak mempengaruhi porsi makan mahasiswa dan mudah mengingat materi yang pernah dipelajari. Stres akademik pada mahasiswa dapat diminimalisir dengan melakukan pengelolaan dalam menghadapi tuntutan-tuntutan akademik dengan cara menenangkan diri dan menjalankan aktifitas 
perkuliahan seperti biasa, berusaha untuk membuat nyaman dengan menikmati setiap proses yang dijalani, berusaha mencari referensi di luar seperti perpustakaan maupun internet, mengerjakan sedikit demi sedikit tugas yang sudah diberikan dosen, membuat manajemen waktu, menyusun jadwal pembuatan tugas dan belajar, serta berpikir positif.

Menurut Potter \& Perry (2005) tingkat stres akademik yang sedang sampai dengan berat dapat menghambat pembelajaran. Hal ini dapat menurunkan kapasitas seseorang yang menyebabkan ketidakmampuan memperhatikan atau mengerjakan sesuatu, seperti tugas perkuliahan. Tingkat stres yang tergolong sedang menunjukkan bahwa individu tersebut memiliki stres akademik yang tidak terlalu tinggi dan tidak terlalu rendah mengahadapi tuntutan akademik di dalam perkuliahan.

Dari identifikasi di atas, diketahui bahwa mahasiswa yang mengalami kondisi flow akademik dalam melakukan tugas perkuliahan atau pada proses pembelajaran ini disebabkan karena mahasiswa tidak mengalami stres pada saat perkuliahan, sehingga mahasiswa mampu mengalami kondisi flow pada proses pembelajaran. Dengan demikian mahasiswa yang sulit mengalami kondisi flow pada tugas akademik cenderung mengalami stres akademik yang tinggi. Hal tersebut, menunjukkan bahwa mahasiswa kurang mampu merasa fokus dan berkonsentrasi pada saat proses pembelajaran berlangsung. Sebaliknya, mahasiswa yang mudah mengalami kondisi flow pada bidang akademik maka mampu berkonsentrasi dan fokus dalam mengerjakan tugas akademik dan tidak akan mengalami stres pada saat perkuliahan berlangsung.

Ketika dilihat dari hasil penelitian ini menunjukan bahwa ada hubungan yang signifikan antara stres akademik dengan flow akademik pada mahasiswa, semakin rendah stres akademik maka semakin mudah mahasiswa mengalami kondisi flow akademik. Mahasiswa yang mampu berkonsentrasi terhadap aktivitas akademik maka akan memunculkan rasa nyaman dan termotivasi untuk lebih baik dari sebelumnya. Ciri-ciri kondisi flow akademik adalah merasakan kenyamanan dalam mengerjakan aktivitas serta ikut serta secara total dalam aktivitas tersebut, sehingga tugas-tugas yang sedang dikerjakan menjadi mudah.

Flow dapat memberikan manfaat positif antara lain dapat membuat mahasiswa lebih fokus, kreatif, lebih mudah menyerap materi pembelajaran, serta dapat mengurangi stres akademik. Hal ini, berdampak pada hasil belajar yang optimal. Mahasiswa yang merasa stres cenderung mengalami perubahan nafsu makan, sulit tidur, dan menangis, ketika mengalami sesuatu yang dinilai melebihi batas kemampuannya (Ignatius, 2013).

Stres akademik tidak hanya menjadi satu-satunya faktor yang dapat mempengaruhi flow akademik. Adapun faktor lain sebagaimana dalam penelitian Kartika (2015) mengatakan bahwa kecerdasan emosi memiliki hubungan negatif dengan stres akademik. Dengan demikian, diketahui apabila kecerdasan emosi seorang individu tinggi maka stres akademiknya akan rendah. Hal ini dikarenakan individu dengan kecerdasan emosi yang baik dapat mengatasi tuntutan dan tekanan di dalam hidupnya. Individu yang mengalami stres akademik tidak mampu mengontrol dan mengatasi tuntutan akademik. Jika mahasiswa mengalami stres dalam hal akademik maka mahasiswa cenderung mengalami kegagalan dalam menyelesaikan 
tuntunan akademik, karena penundaan penyelesaian tugas. Menurut Barseli, dkk (2017), stres akademik adalah persepsi subyektif terhadap suatu kondisi akademik atau respon yang dialami mahasiswa berupa reaksi fisik, perilaku, pikiran, dan emosi negatif yang muncul akibat adanya tuntutan perkuliahan atau akademik.

Mahasiswa yang dapat menghindari respon ataupun gejala yang ditimbulkan dari stres akademik, besar kemungkinan dapat terhindar dari stres akademik. Mahasiswa yang tidak mengalami stres dalam perkuliahan berpotensi dapat mengalami perasaaan flow. Yuwanto (2013) menjelaskan keadaan flow dapat dialami oleh mahasiswa ketika melakukan kegiatan yang berhubungan dengan bidang akademik, seperti mengikuti proses belajar dan pembelajaran dikelas serta mengerjakan tugas yang ada, disebut sebagai flow akademik.

Mahasiswa yang mengalami flow akan menganggap aktivitas yang dikerjakan sangat berharga dan penting untuk dilakukan. Selain itu, seseorang yang sedang mengalami flow cenderung merasa bahwa waktu cepat berlalu, hal ini disebabkan karena adanya perasaan nyaman dan konsentrasi penuh terhadap tugas yang sedang dikerjakan.

Flow akademik bagi mahasiswa berfungsi untuk memberikan pengalaman optimal pada aktivitas yang dilakukan, mudah menerima dan memahami informasi dan keterampilan yang berkembang pada proses kegiatan (Yuwanto, 2013). Mahasiswa yang berada dalam situasi flow akademik mampu melibatkan dirinya serta memiliki konsentrasi penuh terhadap pelajaran yang sedang dijalani dan menunjukkan antusiasnya dalam belajar. Hasil penelitian Yuwanto, Budiman, Prasetyo, \& Siandhika tentang "Stres Akademik dan flow Akademik" menunjukkan bahwa flow akademik mahasiswa berada pada kategori sedang yaitu 52,9\%, ini menunjukkan tidak semua mahasiswa bisa mengalami flow, hal ini disebabkan karena mereka mengalami stres akademik (Arif, 2013).

Fullagar \& Kelloway (2009) menyebutkan bahwa seseorang yang mengalami flow lebih tinggi juga merasa lebih senang, bersemangat dan sebagainya. Ketika mahasiswa mengalami flow dalam kegiatan akademik mereka akan menyadari untuk memperluas kemampuan dan keterampilan pada diri individu dan memberi pengaruh positif pada kegiatan akademik yang dilakukan. Adapun mahasiswa dengan flow akademik yang rendah menunjukkan sikap kurang antusias ketika mengikuti proses belajar dan penyelesaian tugas akademiknya (Prihandrijani, 2016).

Sumbangan efektif dalam penelitian ini sebesar $12,9 \%$ dan sisanya berjumlah 87,1\% yang dipengaruhi oleh faktor lain. Menurut Csikszentmihalyi (2014) Faktorfaktor lain yang memiliki korelasi dengan flow akademik adalah student engagement, motivasi breprestasi, motivasi belajar, dukungan sosial, self esteem, selffficacy dan faktor lingkungan sosial.

\section{SIMPULAN DAN IMPLIKASI}

Berdasarkan hasil penelitian dapat disimpulkan bahwa terdapat adanya hubungan negatif yang cukup signifikan antara stres akademik dengan flow akademik pada mahasiswa, artinya semakin tinggi tingkat stres akademik pada mahasiswa maka semakin rendah tingkat flow akademik yang dirasakan oleh mahasiswa. Sebaliknya, 
jika stres akademik rendah, maka semakin tinggi flow akademik yang dirasakan mahasiswa.

Adapun implikasi pada peneliti selanjutnya disarankan untuk melakukan beberapa hal, yaitu perlu dilakukan penelitian lanjutan untuk mengukur flow akademik dengan variable lain. Selain itu, perlu dilakukan penelitian lanjutan untuk melihat apakah flow akademik dapat dipengaruhi jenis kelamin, tipe kepribadian dan mengukur flow akademik dengan faktor lain yang mempengaruhi.

\section{REFERENSI}

Alvin. (2007). Handling student's stress. Jakarta: Gramedia.

Ansori, S. (2015). Pengaruh Adversity Quotient terhadap stres akademik pada mahasiswa. Skripsi Universitas Muhammadiyah Malang.

Azwar, S. (2012). Metode penelitian. Yogyakarta: Pustaka pelajar.

Bakker, A. B. (2005). Flow among music teachers and their students: The crossover of peak experience. Journal of Vocational Behavior.

Barseli, M., \& Ifdil, I. (2017). Konsep stres akademik siswa. Jurnal Konseling dan Pendidikan.

Csikszentmihalyi, M. (2014). Applications Offlow in Human Development and Education. London: Springer dordrecht heidelberg.

Csikszentmihalyi, M. (1990). Flow: The Psychology of Optimal Experience. New York: Harper \& Row.

Desmita (2010). Psikologi Perkembangan Peserta Didik cetakan ke-5. Bandung: Remaja Rosdakarya.

Furlong, J. M., Gilman, R., Heubner, E. S. (2009). Handbook of positive psychology in schools. Flow in schools revisited: cultivating engaged learners and optimal learning environment.

Goff, A.M. (2011). Stressor, accademic performance and learned resourcefulness in baccalaureate nursing students. International Journal of Nursing Education Scholarship.

Goleman, D. (2015). Emotional intelligence: Kecerdasan emosional, mengapa EI lebih penting daripada IQ. Terj: T. Hermaya. Jakarta: P.T Gramedia pustaka utama.

Hartaji, Damar A. (2012). Motivasi berprestasi pada mahasiswa yang berkuliah dengan jurusan pilihan orangtua. Fakultas psikologi Universitas Gunadarma

Ignatissus, Robin. (2013). Go with the flow: Dukungan sosial dan flow akademik pada mahasiswa. Jurnal Ilmiah Mahasiswa Universitas Surabaya.

Olejnik, S.N \& Holsbhuh, J.P (2007). College rules second edition how to study, survive and success. New york: Ten speed press.

Prihandrijani, E. (2016). Pengaruh motivasi berprestasi dan dukungan sosial Terhadap flow Akademik pada siswa SMA X di Surabaya. Tesis Surabaya: Program studi magister psikologi fakultas psikologi Universitas Erlangga.

Rahmawati, D. D. (2012). Pengaruh self efficacy terhadap stres akademik pada siswa kelas 1 rintisan sekolah bertaraf internasional (RSBI) di SMP Negeri 1 Medan. Jurnal Psikologi Universitas Semarang.

Santrock, J.W. (2003). Adolescene perkembangan remaja. Jakarta. Erlangga.

Santoso, Melisa. (2014). Self efficacy dan flow akademik ditinjau dari temporal motivation theory pada mahasiswa fakultas psikologi. Jurnal ilmiah mahasiswa Universitas Surabaya.

Selye, H. (1992). Selye's guide to stress research. USA: Van nostrand reinhold company Inc.

Shernoff, D.,J Csikszentmihalyi, M., Schneider, B., \& Shernoff, E.,S. (2003). Student engagmentin high school classroom from the perspective of flow theory. School Psychology Quarterly. 
Sho'imah, D.W. (2010) Hubungan Adversity Quotient dan Self Efficacy dengan toleransi terhadap stres pada mahasiswa. Skripsi. Program studi psikologi fakultas kedokteran Universitas Sebelas Maret. Surakarta.

Siswoyo. Dkk. (2007). Ilmu pendidikan. Yogyakarta: UNY Press.

Sugiyono. (2016). Metode penelitian kuantitatif kulitatif dan kombinasi (mixed methods). Bandung.

Yuwanto, L. (2011). The flow inventory for student: Validation of LIS. Indonesia Psychological Journal.

Yuwanto, L. (2013). The nature of flow.Sidoarjo: Dwiputra pustaka jaya. 